Caste-Gender Intersections in Contemporary India

\title{
Afterword: Gendering Caste: Honor, Patriarchy and Violence
}

\section{Hugo Gorringe}

\section{(2) OpenEdition}

1 Journals

Electronic version

URL: https://journals.openedition.org/samaj/4685

DOI: $10.4000 /$ samaj.4685

ISSN: $1960-6060$

Publisher

Association pour la recherche sur l'Asie du Sud (ARAS)

\section{Electronic reference}

Hugo Gorringe, "Afterword: Gendering Caste: Honor, Patriarchy and Violence", South Asia

Multidisciplinary Academic Journal [Online], 19 | 2018, Online since 18 September 2018, connection on 21 September 2021. URL: http://journals.openedition.org/samaj/4685 ; DOI: https://doi.org/10.4000/ samaj.4685

This text was automatically generated on 21 September 2021.

\section{c) $(9)$}

This work is licensed under a Creative Commons Attribution-NonCommercial-NoDerivatives 4.0 International License. 


\title{
Afterword: Gendering Caste: Honor, Patriarchy and Violence
}

\author{
Hugo Gorringe
}

\section{Introduction}

1 The central significance of gender to the operation of caste was vividly highlighted for me during fieldwork on Dalit politics and mobilization in 2012. ${ }^{1}$ I visited the offices of the Communist Party of India (Marxist) (CPM) in Madurai (central Tamil Nadu) to interview the local leader Vikraman. He detailed the work of the Tamil Nadu Untouchability Eradication Front, which has documented the many and varied forms of untouchability practiced in contemporary Tamil Nadu. One example captured the gendered logic of caste divisions:

V: Dalits can't take water from the well, can't use the public pond, can't enter the temple in several villages, can't ride a bicycle even today in some villages, can't wear shoes in some villages. What is really perverse is that Dalits are not allowed to keep male dogs in some villages.

Interviewer: Why?

V: In case the Dalit's male dog mates with a non-Dalit's female dog, do you understand, so Dalit can't keep a male dog at home. ${ }^{2}$

Several respondents repeated this restriction to me. In each case there was sense of incredulity and ridicule about the lengths to which dominant castes would go to retain their superiority. The story was often accompanied by laughter, brought on more by disbelief than any humor inherent to the situation. We can discern the operations of casteism in its varied forms encapsulated in this instance. For a start, following Natrajan, casteism is revealed to be "a set of monopolistic practices that uses modes of exclusion, domination, exploitation and stigmatization" (author's emphasis, 2012:xvi). Secondly, the instance highlights how caste is not a static or timeless social structure but a shifting complex of social relationships. Thirdly, it points to the collective nature of casteism, such that even pets are perceived to "have caste" by association. Finally, and most pertinently for this paper, we see the inextricable intermeshing of caste and gender. Just 
as purity concerns have never safeguarded Dalit women against the sexual predations of dominant men, it is no surprise nor coincidence that it is male dogs that are denied to Dalits. Caste, as Ambedkar (2011) noted, rests upon endogamy. In this sense, as Velaskar (2016) observes, women feature "as gateways to caste through whom caste purity could be threatened and caste status could be claimed" (p. 391). As an EPW Editorial (2013) puts it, it follows-and the papers in this volume make clear-that "caste cannot be fought without fighting patriarchy" (p. 8). Each paper in this volume draws on rich empirical research to emphasize how the intertwined nature of caste and gender is palpable in terms of livelihoods, social relations and the experience of-and reaction to-caste violence. Subjecting the social structures of caste to critical scrutiny and revealing the intersections of caste-class and gender, as the papers in this issue do, will not only advance our understanding of contemporary social formations, but help to address the inequalities they erect as well.

\section{Understanding caste}

2 In his excellent overview of theorizations of caste, Jodhka (2015:5) delineates three key scholarly approaches to the subject: caste as tradition, caste as power politics and caste as humiliation. The first school roughly equates to the Dumontian position which draws on classic Hindu texts to paint a picture of an unchanging Indian civilization which is radically different to Western societies. Caste-based stratification, according to this line of thought, is so far removed from the social mobility and individualism of the West as to defy comparison. Dumont (1980) and others view caste as a holistic and interdependent set of relations in which material wealth and power are subordinate to status. Dumont's work was enormously influential, but has been subject to numerous critiques from those who adhere to what Jodhka terms the "caste as power" approach.

The central contention of this school is that caste relations are not-and have never been -divorced from power and politics (Srinivas 1996). These more empirical studies note that caste positions are negotiated at a local level and may change over time. Whilst individual mobility may be restricted to movement within a caste, whole castes like the Nadars of Tamil Nadu have occasionally managed to improve their collective social standing (Hardgrave 1969). Scholars such as Dirks (2001) point to the central significance of monarchs to various caste systems across India and observe how caste as we know it today has been shaped by British intervention. Barnett (1977:396-97) notes how caste as a set of practices shifted from adherence to a localized code of conduct to wider groupings based around a notion of blood-purity. ${ }^{3}$ This shift facilitated the creation of caste associations and fueled the rise of caste politics since it allowed for geographically dispersed groups to conceive of themselves as members of the same caste group.

The third view, Jodhka (2015:12) argues, sees caste as "a system that institutionalizes humiliation as a social and cultural practice." These bottom-up accounts became salient in the 1990s with the rise of Dalit mobilization and politics, and offered an experiential reading of caste. Jodhka further argues that it was at this point in time that Ambedkar was rediscovered as a political and social icon who has become increasingly central to political practice and theory. Indeed, Jodhka (2015) insists that "no discussion of caste today is possible without invoking Ambedkar and his critique of caste and Hindu society" (p. 13). These empirical or practice-based theories and Ambedkar's (2011) understanding of caste as a form of graded inequality are important in understanding the persistence of 
caste in contemporary India. This approach viewed caste as a form of institutionalized domination and, as Beteille (1990) notes, is most compelling when considering "the sexual use and abuse of women, which is an aspect of the inequality of power, seen in its most extreme form in the treatment of women of the lowest rank by men of the highest" (p. 491). Dalit respondents in the late 1990s, spoke of routinized sexual predation as an expression of caste dominance (see Gorringe 2005).

5 It is clear that the Constitution and emergence of human rights norms have eroded the legitimacy of caste-based discrimination, even whilst numbers of atrocities remain appallingly high (Jha 2016). During the Constituent Assembly debates in 1949, Ambedkar pointed to the contradictions inherent to the establishment of the Republic and noted how the principle of political equality sat uncomfortably alongside a "social and economic structure, [which will] continue to deny the principle of one man one value" (Moon 1994:1216). Indeed, it has taken sustained socio-political mobilization to challenge overt practices of casteism and problematize open expressions of caste-based discrimination (cf. Carswell and De Neve 2015; Waghmore 2016). In response to such challenges, Natrajan (2012) argues, caste associations and practitioners seek to neutralize critique via a "culturalization of caste" (p.5) in which difference and culture are emphasized over hierarchy. This is one effort, as Jodhka (2015) puts it, "to explore what makes it possible for caste to reproduce itself even outside its 'traditional' social universe, the Indian village" (pp.17-18). Such explanations of castes as discrete entities are appealing but, as Natrajan (2012) observes, they obscure the fact that "endogamous practices exist" not just because of cultural "differences," but "to enable patriarchy and the reproduction of patriarchal and caste privilege" (p. 17; cf. Rao 2018).

\section{Gendering understandings of caste}

6 As Irudayam, Manghubhai and Lee (2014) contend, "to understand the reality of caste in Indian society in general, and the Dalit community and Dalit women in particular, an analysis of interlinking caste-class-gender dynamics is imperative" (p. 5). Rege's (2013:20) theoretical revisiting of Ambedkar through a gendered lens, and Chakravarti's (1993) work on Brahminical patriarchy have been pivotal in this respect. Rege (2013) demonstrates that Ambedkar "viewed caste and gender as entangled, but never just easily equated," and sought to "move beyond the binaries of sameness/difference" (p. 20). This is a crucial point. Whilst some feminists continue to neglect caste and some Dalit critiques of caste still neglect patriarchy, Ambedkar's work illuminated how caste rests upon sexual regulation (cf. Rao 2009; Geetha 2009). Thus, his call for inter-caste marriages and the reform of family laws were designed to undermine this pillar of caste hierarchy and posed a fundamental challenge to the caste order. ${ }^{4}$ As Geetha (2009) notes, "love in a caste society is ... an intensely regulated phenomenon" (p. 99). In independent India, the state ostensibly supports and encourages inter-caste unions. Indeed several state Governments, such as that in Tamil Nadu, offer financial incentives to cross-caste couples. Nevertheless, they remain rare and may lead to violence and/or a loss of family support (cf. De Neve 2016).

7 Whilst violence may be used to punish cross-caste unions, the proscription on transgressive love has never extended to sexual violence across caste boundaries. Whilst Rao (2009) is right in some ways to argue that "sexual violence is particularly indecipherable as caste violence" (p.222), therefore, in other respects her work 
emphasizes that it is in fact the epitome of caste violence. Indeed, she goes on to argue that "sexual violence performed a pedagogical function in socializing men and women, Dalit and caste Hindu alike, into caste norms" (2009:234). Writing against the tendency to describe violent events as either caste atrocities or sexual atrocities, Rege (2013) calls on us "to map the ways in which woman as a category is ... differently reconstituted within patriarchal relations of gendered caste inequalities" (p. 20). This point is reinforced by the work of academic and activist Gabriele Dietrich. She notes how the intersections of patriarchy and caste play out in Dalit movements in which police and upper caste violence against Dalit women are highlighted even as intra-Dalit violence may be swept under the carpet. Even casteist sexual-violence may be downplayed at times: "Dalit leaders may have their own patriarchal interests in using or suppressing an assault on a woman" (Dietrich 2001:204). She cites an example in which a rape case was registered as "attempted rape" in order to uphold the "honor" of the victim's husband.

8 The problematic and contentious concept of "honor" is one of the key points of intersection between caste and patriarchy. Caste honor, Gupte (2013) observes, is "largely centered on the behavior of women" (p. 73), and as Welchman and Hossain (2005) argue, is "vested in male (family and/or conjugal) control over women and specifically women's sexual conduct: actual, suspected or potential" (p.4). One of the prime means of demeaning Dalits is to defile the honor of Dalit women, thus casting aspersions on the manhood of Dalit males (who cannot protect their women) and on the chastity of Dalit women (presuming they survive upper caste rape rather than killing themselves). The obverse of honor is shame and failure to protect the inviolability of Dalit women leads to collective humiliation (cf. Delaney 1987). Whilst Dalit leaders rightly view endogamy as central to caste and critique it accordingly (Ambedkar 2011; Thirumavalavan 2004), the actions of assertive and upwardly mobile Dalit activists may simultaneously reinforce patriarchy (Anandhi, Jeyarajan, and Krishnan 2002).

9 The condemnation of casteist violence and discourses of honor, often fails to inform more mundane and everyday processes. The pervasive nature of concerns around propriety is seen in the fact that Dalit women activists are subject to moral scrutiny by fellow activists (Gorringe 2017). Public political utterances may also fail to inform domestic arrangements and expectations. Grover's (2011) work in Delhi, for example, details how female sweepers must continuously behave with honor and respectability to ward off accusations of infidelity from their husbands. Still's (2014:90-92) work in Andhra Pradesh helps to explain this trend in suggesting that "honor," and the associated "respectability" of women, has become central to Dalit pursuits of social status and upward mobility. She documents the rise of a patriarchal conservatism based on a male breadwinner model which runs counter to the radicalism of Dalit mobilization (Still 2014:16). Carswell (2016) likewise argues that Dalit women's withdrawal from paid work in Western Tamil Nadu "was clearly associated with strong socio-economic aspirations and a tightening of patriarchal controls" (p.135). Still (2014) contends that this conservatism must be understood and analyzed in a wider social context, within which social status is mapped onto the behavior of women. Still (2014) notes that Telegu descriptions of Dalit women as "lacking in manners and refinement, unselfconscious, careless, indiscriminate, promiscuous, disorderly, and sexually rapacious and therefore in need of "civilization"" (p. 95) serve both to construct Dalit women as sexually available and to demarcate Dalits as a group that lacks social standing. 
10 "Individual honour," as George (2006:37) reminds us, "is usually subsumed to family and religious or community honour," but what it means to be "honorable" is gendered (see Hebbar 2018, this volume). While male "honor" rests on their ability to control women's bodies (Welchman and Hossain 2005; Rao 2018 and Hebbar 2018, this volume), female honor entails conforming to appropriate and sanctioned roles and codes of conduct (Still 2011; Grover 2011). The "obsessive need for control over women," which Chakravarti (1993:582) sees as central to Brahminical patriarchy lies at the heart of gendered discourses of honor. As Dalits have escaped dependency and sought to alter their social standing, they have valorized male physical strength and control over women and reveled in the ability to tease, taunt and woo women from higher castes (Anandhi, Jeyaranjan, and Krishnan 2002) whilst simultaneously "controlling Dalit women in the name of honour" (Still 2011:1144). It is against this backdrop that the politics of honor are so central a part of caste politics in contemporary India, as the papers in this volume demonstrate so forcefully (see Rao 2018, Hebbar 2018 and Kunduri 2018, this volume). At the same time, the intersectional lens adopted by many of the papers alerts us to the need for nuanced analysis. Kapadia (2010) rightly cautions against "increasing patriarchalisation" (p. 269) amongst Dalits, but it is also important to note the arduous and low-paid (often bonded) nature of the employment available to lower-caste and -class women. In such circumstances, escaping exploitative and demeaning labor may be "a choice that some Dalit women are nowadays lucky to be able to make" (Carswell 2016:141), even if-as Rao (2018, this volume) highlights-women's choices continue to be constrained by caste and patriarchal control. Hebbar (2018), Kumar (2018) and Kunduri's (2018) papers (this volume) illustrate how concerns over status inform new interactional patterns and gender norms and shape the choices that women can make. While in Kumar's (2018) paper this relates to questions of caste pride, Hebbar (2018) and Kunduri (2018) illustrate how status production is often an act of rendering caste affiliation invisible. The key questions here revolve around whose voices are heard and what options are available.

\section{A palace on a dung-heap}

11 In his impassioned resignation statement, following the defeat of the Hindu Code Bill, Ambedkar (1995) famously observed that: "To leave inequality between class and class, between sex and sex which is the soul of Hindu Society untouched and to go on passing legislation relating to economic problems is to make a farce of our Constitution and to build a palace on a dung heap" (p.1326). The papers in this special issue attest to the validity of Ambedkar's judgment. The Hindu Code Bill, as Rege (2013) highlights, "posed the imminent threat of women gaining access and control over resources and property, the possibility of removal of restrictions of caste in marriage and adoption, and the dawn of the right to divorce" (p. 200). The measures in the draft legislation, in other words, promised to undermine the "very core of Brahminical patriarchy" (p. 200). The papers by Kumar, Kunduri and Rao, highlight how everyday livelihoods and strategies continue to be informed by, and embedded in, intersections of caste, class and gender identities that shape access to work, resources and livelihood opportunities.

12 It was Ambedkar's appreciation of caste's multifaceted character that afforded him this insight. Sadly, such analysis has all too often been absent from scholarly work on caste, and still less has it informed activism and policy. Shorn of such insight, the radicalism of 
Dalit or feminist assertions may be strictly enclosed within the parameters of caste society. Caste, in such approaches, may be understood not as hierarchy but as "difference" and viewed in cultural terms that do "not problematize the principle of separation (mutual repulsion) nor the rampant ordering or stigmatization of castes" (Natrajan 2012:169). Accepting-or even celebrating-caste as a resource, or a form of "social capital," neglects how caste "networks reinforce socio-economic hierarchies and generate new forms of exclusion" (Vijayabaskar and Kalaiyarasan 2014:34). This volume contributes to a growing body of scholarship (cf. Anandhi, and Kapadia 2017; Ciotti 2017), which highlights the imperative for an intersectional reading of caste that appreciates the "cumulative" nature of social inequalities (Oommen 1984) and the mutually constitutive nature of social identities. This reinforces the requirement for policymakers, activists and academics to acknowledge and address the various intersections that characterize social inequality in India.

To build our analyses of caste without such comprehension is surely to construct our intellectual frameworks upon a dung heap. It is only by grasping the interlocking and cumulative nature of disadvantage that we can explain the persistence of caste-based atrocities in contemporary India and the culture of impunity which allows perpetrators to escape justice time and again. The authors in this collection perform a valuable service in foregrounding how the intersections of caste and gender continue to inform empirical manifestations and adaptations of social stratification. The caste system, Deshpande (2011) argues, "not only determines the social division of labor, but its sexual division as well" (p.107). Endogamy, she suggests, may be seen as a means of controlling the sexuality and labor of women. Gendered patterns of labor are not only shaped by caste, however, they are determined by class and regional identities, as well as ways of understanding labor that are subject to change over time. Thus, historically, higher castes imposed more constraints on women than the more egalitarian Dalit castes. This, as Rao (2018, this volume) shows is starting to change. Crucially, in Rao's case study, it is the women themselves who are determining their destinies and deciding to withdraw from work so as to focus on their children amongst other things (cf. Carswell 2016). As the papers by Kumar (2018, this volume) and Kunduri (2018, this volume) highlight, such decisions and strategies occur within socio-cultural frameworks that rest upon casteist understandings of masculinity and femininity. Such norms and practices are increasingly subject to challenge, resulting in what Mendelsohn and Vicziany (1999) refer to as a "new" form of violence by caste Hindus "to the changing situation of Untouchables" (p. 45). Irudayam, Mangubhai, and Lee (2011), likewise, point to the systematic use of violence to shore-up or reinforce caste privilege.

14 Faced with this harsh reality, the All India Democratic Women's Association has demanded the enactment of a comprehensive law on honor crimes. Irudayam, Mangubhai and Lee (2011) have called for "supportive mechanisms" both to aid those facing violence but also to document and amplify the voices of Dalit women themselves so as to end the culture of impunity around caste violence. However, these mechanisms, must be attuned to the intersectional nature of social identities and structures. Failure to appreciate the intersectional nature of oppression has led, as the introduction emphasizes, to feminist movements that have neglected caste-based oppression and Dalit movements which have been silent on issues such as domestic violence and dowry. Following the Delhi rape case of 2012, for instance, Dalit women highlighted how routinized and endemic the sexualized violence of caste was and pointed to the absence of a moral outcry for Dalit 
victims (Dutta and Sircar 2013). Javaid (2015) cites the probing question posed by Mashaal, a Dalit women's rights activist: "But what about Dalit women's rapes that occur due to the intersectionality of gender, caste, and class? These rapes are not even allowed to be registered in police stations." If the inaction and apathy of the state is a given, Dietrich (2001) notes how women have had to carve out a space within the Dalit struggle to articulate concerns over violence, access to water and crèche facilities that are all neglected by malestream Dalit organizations as "women's issues." In light of the above analysis the imperative for research and activism that is sensitive to the compound nature of oppression is clear.

We must embrace the insight that a categorical identity-such as "Dalit women"-"is not a behavioral entity" (Foss and Larkin 1986:131). Dalit women act on the basis of the same compulsions, impulses and rationales as others. We should also be alert to the fissures within the Dalit category along both caste and class lines (Carswell 2016). This constitutes a first step towards recognizing the agency and individuality of women. Doing so, as Rege (2013) notes, would be to accept the women as active and politically equal Indian citizens, and not merely the bearers of "the 'honor' of the family, kinship and community" (p. 193). The collection of papers in this special issue may, in this light, be conceived of as part of a wider project that dispenses with characterizations of women-and Dalit women in particular-as victims and follows their lead in subjecting social formations to critical analysis and scrutiny.

\section{BIBLIOGRAPHY}

Ambedkar, Bhimrao. 1995. Writings and Speeches: Volume 14(2), edited by V. Moon. Mumbai: Government of Maharashtra.

Ambedkar, Bhimrao. 2011. Annihilation of Caste. Nagpur: Prabuddha Bhart Pustkalya.

Anandhi, S, J. Jeyaranjan, and Rajan Krishnan. 2002. "Work, Caste and Competing Masculinities: Notes form a Tamil Village." Economic and Political Weekly 37(43):4397-406.

Anandhi, S and Karin Kapadia, eds. 2017. Dalit Women: Vanguard of an Alternative Politics in India. New Delhi: Routledge.

Barnett, Steve. 1977. "Identity Choice and Caste Ideology in Contemporary South India." Pp. 393415 in The New Wind, edited by K. David. The Hague: Mouton Publishers.

Beteille, Andre. 1990. "Race, Caste and Gender." Man 25(3):489-504.

Carswell, Grace. 2016. "Struggles over Work Take Place at Home: Women's Decisions, Choices and Constraints in the Tiruppur Textile Industry, India." Geoforum 77:134-45.

Carswell, Grace, and Geert De Neve. 2015. "Litigation against Political Organisation? The Politics of Dalit Mobilisation in Tamil Nadu, South India." Development and Change 46(5):1106-32.

Chakravarti, Uma. 1993. "Conceptualising Brahminical Patriarchy in Early India." Economic and Political Weekly 27(14):579-85. 
Ciotti, Manuela, ed. 2017. Unsettling the Archetypes: Femininities and Masculinities in Indian Politics. New Delhi: Women Unlimited.

Delaney, Carol. 1987. "Seeds of Honor, Fields of Shame." Pp. 35-48 in Honor and Shame and the Unity of the Mediterranean, edited by D. Gilmore. Washington: American Anthropological Association.

De Neve, Geert. 2016. "The Economies of Love: Love Marriage, Kin Support, and Aspiration in a South Indian Garment City." Modern Asian Studies 50(4):1220-49.

Deshpande, Ashwini. 2011. The Grammar of Caste: Economic Discrimination in Contemporary India. New Delhi: Oxford University Press.

Dietrich, Gabriele. 2001. A New Thing on Earth. Delhi: ISPCK.

Dirks, Nicholas. 2001. Castes of Mind: Colonialism and the Making of Modern India. Princeton, NJ: Princeton University Press.

Dumont, Louis. 1980. Homo Hierarchicus: The Caste System and its Implications. Chicago: University of Chicago Press.

Dutta, Debolina, and Oishik Sircar. 2013. “India's Winter of Discontent: Some Feminist Dilemmas in the Wake of a Rape." Feminist Studies 39(1):293-306.

EPW Editorial. 2013. “Fighting Caste, Fighting Patriarchy." Economic and Political Weekly 48(29):8.

Foss, Daniel and Ralph Larkin. 1986. Beyond Revolution: A New Theory of Social Movements.

Massachusetts: Bergen and Garvey.

Geetha, V. 2009. "Bereft of Being: The Humiliations of Untouchability." Pp. 95-107 in Humiliation: Claims and Context, edited by G. Guru. New Delhi: Oxford University Press.

George, Annie. 2006. "Reinventing Honorable Masculinity: Discourses from a Working-class Indian Community." Men and Masculinities 9(1):35-52.

Gorringe, Hugo. 2005. Untouchable Citizens: Dalit Movements and Democratisation in Tamil Nadu. New Delhi: Sage.

Gorringe, Hugo. 2017. "Questions of Honour: Dalit Women Activists and the Rumour Mill in Tamil Nadu." Contemporary South Asia 25(3):255-69.

Grover, Shalini. 2011. Marriage, Love, Caste and Kinship Support: Lived Experiences of the Urban Poor in India. New Delhi: Social Science Press.

Gupte, Manisha. 2013. “The Concept of Honour: Caste, Ideology and Patriarchy in Rural Maharashtra." Economic and Political Weekly 48(18):72-81.

Hardgrave, Robert. 1969. The Nadars of Tamilnad. Berkeley: University of California Press.

Hebbar, Nandini. "Subjectivities of Suitability: 'Intimate Aspirations' in an Engineering College." SAMAJ 18. Retrieved June 7, 2018 (https://journals.openedition.org/samaj/4578).

Irudayam, Aloysius, Jayshree Maghubhai, and Joel Lee. 2011. Dalit Women Speak Out. New Delhi: Zubaan.

Javaid, Maham. 2015. “How India's 'Untouchable’ Women Are Fighting Back against Sexual Violence.” Refinery 29, October 15. Retrieved June 16, 2017 (http://

www.refinery29.com/2015/10/95759/dalit-untouchable-women-india-sexual-violence). 
Jha, Ashok Kumar. 2016. “The Dalits - Still Untouchable.” India Today, February 3. Retrieved June 19, 2017 (http://indiatoday.intoday.in/story/dalits-untouchable-rohith-vemula-castediscrimination/1/587100.html).

Jodhka, Surinder. 2015. Caste in Contemporary India. New Delhi: Routledge.

Kunduri, Eesha. "Between Khet (Field) and Factory, Gaanv (Village) and Sheher (City): Caste, Gender and the (Re)shaping of Migrant Identities in Urban India." SAMAJ 18. Retrieved June 7, 2017 (https://journals.openedition.org/samaj/4582).

Mendelsohn, Oliver and Marika Vicziany. 1999. The Untouchables: Subordination, Poverty and the State in Modern India. Cambridge: Cambridge University Press.

Moon, Vasanth, ed. 1994. Dr. Babasaheb Ambedkar: Writings and Speeches. Vol. 13. New Delhi: Government of Maharashtra. Retrieved September 13, 2018 (https://www.mea.gov.in/Images/ attach/amb/Volume_13.pdf).

Natrajan, Balmurli. 2012. The Culturalization of Caste in India. London: Routledge.

Oommen, Tharailath. 1984. "Sources of Deprivation and Styles of Protest." Contributions to Indian Sociology 18(1):45-61.

Rao, Nitya. 2018. "Fertility, Reproduction and Conjugal Loyalty: Renegotiating Gender Relations amongst Dalits in Rural Tamil Nadu." SAMAJ 18. Retrieved June 7, 2018 (https:// journals.openedition.org/samaj/4575).

Rao, Anupama. 2009. The Caste Question: Dalits and the Politics of Modern India. Ranikhet: Permanent Black.

Rege, Sharmila. 2013. Against the Madness of Manu. New Delhi: Navayana.

Sampath, P. 2010. "Experiences of Struggles against Untouchability in Tamilnadu." The Marxist 26 (1):39-60

Still, Clarinda. 2011. "Spoiled Brides and the Fear of Education: Honour and Social Mobility among Dalits in South India." Modern Asian Studies 45(5):1119-46.

Still, Clarinda. 2014. Dalit Women: Honour and Patriarchy in South India. Delhi: Social Science Press.

Srinivas, M. N. 1996. Village, Caste, Gender and Method. Delhi: Oxford University Press.

Thirumavalavan, Thol. 2004. Talisman: Extreme Emotions of Dalit Liberation. Translated by M.

Kandasamy. Kolkata: Samya.

Vijayabaskar, M., and A. Kalaiyarasan. 2014. "Caste as Social Capital: The Tiruppur Story.”

Economic and Political Weekly 49(10):34-38.

Waghmore, Suryakant. 2016. "Challenging Normalised Exclusion.” Pp. 153-77 in From the Margins to the Mainstream, edited by H. Gorringe, R. Jeffery, and S. Waghmore. New Delhi: Sage.

Welchman, Lynn and Sara Hossain. 2005. “'Honour,' Rights and Wrongs." Pp. 1-21 in "Honour": Crimes, Paradigms, and Violence against Women, edited by L. Welchman and S. Hossain. London: Zed Books. 


\section{NOTES}

1. This research, on Dalit politics in Tamil Nadu, was funded by an ESRC Grant (RES-062-23-3348), for full details see Gorringe (2017). I am grateful to Supurna Banerjee for encouraging me to write this piece, and for comments on earlier drafts.

2. Interview, March 2012.

3. See Beteille (1990) for an interesting comparison of how "code" and "substance" are viewed in race and caste.

4. I am grateful to one of the reviewers for highlighting that Ambedkar's analysis here did not critique the institution of marriage and, as such, remained grounded in a heterosexual and normative vision of sexuality. That said, Rege (2013) argues that the import of Ambedkar's interventions on the Hindu Code Bill was "to recognise the politically equal Indian woman citizen as an individual, and not merely as the bearer of the 'honour' of the family, kinship, and community" (p. 193).

5. http://www.refinery29.com/2015/10/95759/dalit-untouchable-women-india-sexual-violence

\section{INDEX}

Keywords: gender, caste, honor, violence, patriarchy

\section{AUTHOR}

HUGO GORRINGE

University of Edinburgh 